\title{
Molecular and cellular mechanisms underlying the tactile sensation
}

\author{
Ryo Ikeda \\ Department of Orthopaedic Surgery, Jikei University School of Medicine
}

\begin{abstract}
The sense of light touch is indispensable for environmental exploration, social interaction, and skilled tasks but the underlying mechanisms are largely unknown in mammals. Tactile dysfunction such as neuropathic pain produce allodynia which is grievous pain generated by light touch. This intractable phenomenon is induced by neural sensitization after the damage to nervous system. Along with the nervous system mechanisms, mechanotransdcution in the tactile end organs play a crucial role to form mechanical allodynia. Thus, the elucidation of touch mystery is great expected matter to develop the effective treatment against mechanical allodynia. Merkel discs are one of the tactile special end organs thought as putative mechanoreceptors in the skins and can make sophisticated discrimination. We performed in situ patch-clamp recording from Merkel cells which compose Merkel discs in company with $\mathrm{A} \beta$-afferent nerve endings. As a result, Merkel cells showed transduction of tactile stimuli via "Piezo2" channels and encode tactile signals in the form of $\mathrm{Ca}^{2+}$ action potentials. Recent advances using conditional knock out mice also show the same molecular mechanisms for Merkel cells mechanotransduction. These findings provide new insights into how to achieve delicate tactile sensation and may have clinical therapeutic implications.
\end{abstract}

Keywords

Touch; Mechanotransduction; Merkel discs; Mechanically activated channel; Piezo

Received: 1 December 2015

\section{触覚検出の細胞分子機構}

\section{池田 亮}

東京慈恵会医科大学 整形外科学講座 


\section{はじめに}

触覚は, 社会的交流や環境探索そして洗練さ れた技術の獲得など日常生活に必要不可欠な感 覚である 20)。生物学的側面だけでなく，特殊 な義手や災害対応ロボットなどの生体工学にお いても，触れる物の形状や素材を的確に感じ取 ることは，手技や生活の向上につながる 16,29)。 この触覚機能が破綻し, 生活の質が著しく低下 する病態に触覚性疼痛がある。帯状疱疹, 複合 性局所疼痛症候群，神経絞扼などの神経障害で 生じる病的な症状の一つであり, 優しい触刺激 が耐え難い激痛になる。この難治性疼痛の成立 機序は複雑で，主病変に引き続いて起こる中枢 神経内の可塑的変化が原因と考えられてい る33)。しかしながら，新たに構築された神経 ネットワークへ外界からの触刺激情報を伝える 触覚検出の細胞分子機構は, 触覚そのものの研 究が立ち遅れていることから，これまで明らか でなかった。ここで注目すべき検出機構が，機 械刺激を電気シグナル変換するメカノトランス ダクションである4)。生体の皮膚には，このメ カノトランスダクションに関わる特殊な感覚受 容器が存在し, 特に二点識別や優しく触れられ るなどの瀻細な認識を担う Merkel 触盤は，触 覚性疼痛の病態を理解するだけでなく新たな治 療法を確立する上でも，その機構解明が長らく 待たれていた受容器である 19)。そこで本稿で は，触覚受容器 Merkel 触盤で明らかになった 研究成果を中心に, 触覚検出に関連する細胞分 子機構について概説する。

\section{触覚受容器}

個体が環境変化に対応し，危機回避を行うた めに必要な感覚が，触覚である。この原始的な 感覚は，無脊椎動物から哺乳類にいたるまでど の生物にも存在するが, 進化の過程で触刺激を 検出する受容器は, 神経終末単体から, シュワ ン細胞やケラチノサイトなどニューロン以外の 細胞とともに構成される複雑な構造体へ変化を 遂げている。この特殊受容器の代表的なもの に, Meissner 小体, Pacinian 小体, Ruffini 小 体乞して Merkel 触盤があり，生体の皮虐の異 なる層に存在して幅広い触刺激に対応する ${ }^{15)}$ 。 例えば，Meissner 小体であれば皮膚の動的変 形, Pacinian 小体は振動, Ruffini 小体は伸 張，Merkel 触盤は押し返しといった機械刺激 を特殊な形態で検出し $\mathrm{A} \beta$ 求心性神経に伝達す る（Fig.1）。伝達された触刺激は，後根神経節 (DRG) ニューロンにおいて刺激の開始と終了 にのみにインパルスを生じる速順応型（rapidly adapting: RA）あるいは刺激のあいだ持続的に インパルスを生じる遅順応型 (slowly adapting: SA）に変換される (Fig.1)。さらに，2種類の応 答様式は, 反応する振動数の違いやインパルス の性状によって RA I，RA II，SA I， SA II に 細分され，前脊鹃有視床路や後索路を通じて脳内 体性感覚野で統合処理される ${ }^{8)}$ 。触覚受容器か ら始まるこの一連の伝達様式は, 感覚生理の基 礎として広く認識されてきたが，未だ謎のまま となっている根幹の機構が, 受容器内で行われ るメカノトランスダクションである。 


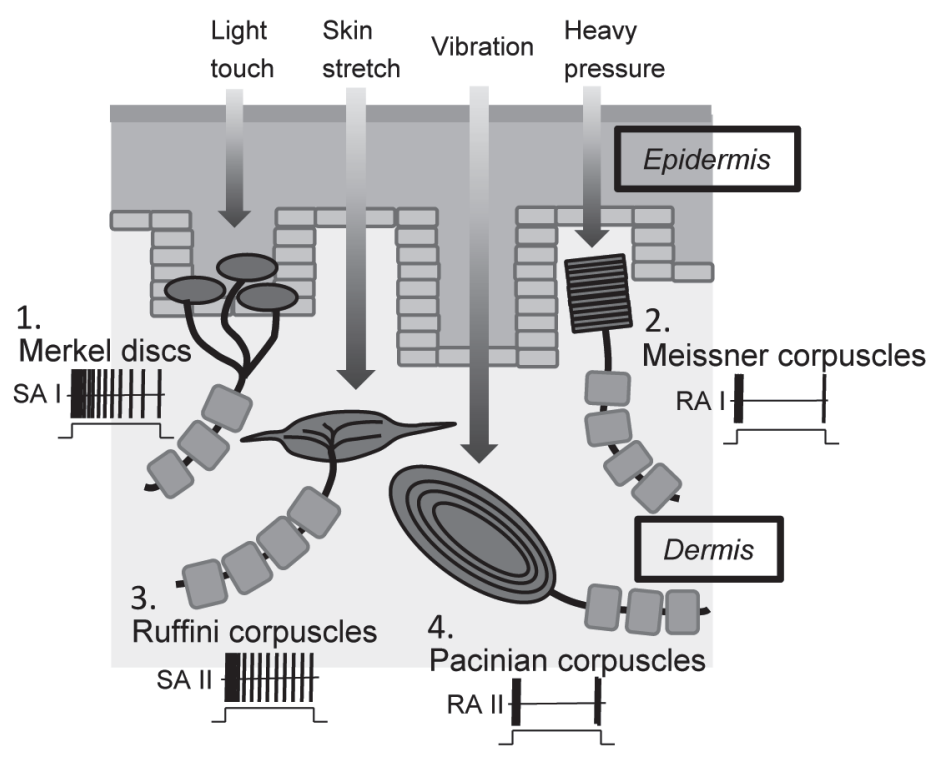

Fig.1 Schematic illustration of the special end organs in the glabrous skin.

1. Merkel discs are placed on the basal layer in epidermis and mediate SA I responses.

2. Ruffini endings are located in dermis and mediate SA II responses.

3. Meissner corpuscles are located in the dermal papillae and mediate RA I responses.

4. Pacinian corpuscles are located in subcutis and mediate RA II responses.

Every organ is associated with $A \beta$ afferent fibers.

\section{Merkel 触盤の触覚検出機構}

物体の形状，質感などの繊細で敏感な触覚を 識別し中枢神経に伝達する Merkel 触盤は，4 〜 50 個に及ぶ Merkel 細胞とそれらを支配する 1 本の $\mathrm{A} \beta$ 求心性神経から成る複合体である。 1875 年にドイッ人解剖学者 Friedrich Merkel によって発見され，人間の指や口唇，げっ歯類 の洞毛など鋭敏な応答を必要とする器官に数多 く存在する 12)。特に, $1 \mathrm{~mm}^{2}$ あたりに通常の 15 倍量の Merkel 細胞が集合して Merkel 触盤 塊を形成する上皮組織は“touch dome”と呼ば れ，非常に高い感受性を持っている30)。触盤 内で求心性神経終末とシナプス様構造を持つ

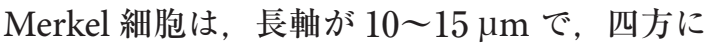

伸びる触手様の突起を持ち, 細胞質内にグル夕 ミン酸，サブスタンス P， ATP，セロトニンな ど数種類の神経伝達物質を含む小胞を保有 する 22)。培養 Merkel 細胞では, 剪断力や低浸 透圧性細胞膨張による機械刺激に対して $\mathrm{Ca}^{2+}$ 応答を生じることから, 触覚検出への関与が示 唆されてきた3)。しかしながら，メカノトラ ンスダクションを担う分子機構の直接的証明が なされなかったため, 触刺激を知覚する感覚細 胞として存在しているのか, 単なる神経終末の 支持組織でしかないのか長い間議論されて きた11,24)。Merkel 細胞において，機械刺激に 対する明らかな電流応答が認められなかった要 因は，センサーとして働く触手様突起物が，培 養によって退縮し機能しなくなること, また, 最も効果的に細胞特性を評価できるパッチクラ 
ンプ法の導入が技術的に困難であったことによ

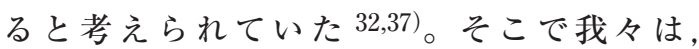
Merkel 細胞周囲の環境を保持したラット洞毛 のリビングセクションを作製, in situ パッチク ランプ法を開発して細胞の電気生理学的特性 を検討した 14)。その結果，Merkel 細胞が電位 依存性 $\mathrm{Ca}^{2+}$ チャネルを介して活動電位を発生 する興奮性細胞であることが明らかになった。 さらにガラスプローブを用いたわずか数 $\mu \mathrm{m}$ の細胞膜変位による機械刺激に対して, Merkel 細胞が確かに応答し速順応型の内向き 電流を生じることがわかった。細胞への直接刺 激だけでなく，より自然な触刺激と考えられる 洞毛の毛幹刺激によっても同様の機械活性化電 流が生じ，接続する求心性神経に SA I 応答を

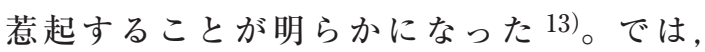
Merkel 細胞のメカノトランスダクションを担 う分子機構は何であろうか。ここで注目すべき 蛋白が，機械活性化チャネルである。

\section{機械活性化チャネル}

1999 年に McCarter らは，ラット培養 DRG ニューロンに機械刺激を加えると，それに応答 して電流が発生することを報告した ${ }^{25)}$ 。細胞 膜をガラスプローブで変位して記録できるこの 応答電流は, その減衰時定数によって rapidly adapting (3 6 $\mathrm{ms})$, intermediately adapting (15 30 ms), slowly adapting $(200 \sim 300 \mathrm{~ms})$, ultra-slowly adapting ( 1000 ms) の 4 種類に 区別される。いずれの電流も重金属の Gadolinium や Ruthenium red, 蛍光指示薬 FM1-43 によって抑制され， $\mathrm{Ca}^{2+}$ 優位の非選択 的陽イオン透過性を持つことが報告されてい
る8)。このように，哺乳類における体性感覚 ニューロンの機械活性化電流特性は次第に明ら かにされてきたが，その分子機構については未 解明のままであった。一方, Caenorhabditis elegans (C. elegance) や Drosophila larvae など の無脊椎動物では, 触刺激検出機構のシンプル な構造的特性から研究が進み, degenerin/ epitherial $\mathrm{Na}^{+}$チャネル $(\mathrm{DEG} / \mathrm{ENaC})$ サブユ ニットの MEC4や26), TRPチャネルファミ リーの NOMPC が 38)，メカノトランスダク ションを担う分子機構として同定されている。 これら候補チャネルの相同体が，哺乳類の触覚 受容器や DRGニューロンにも数多く発現して いる。

\section{Acid-sensing ion channels (ASIC)}

$\mathrm{DEG} / \mathrm{ENaC}$ の相同体であり, ASIC1, ASIC2, ASIC3 の 3 種類のメンバーから成る (Fig.2)。ノックアウトマウスを用いた実験で, いずれのチャネルも侵害刺激以外の皮膚刺激に 関与しないことが行動実験で示された 27,31)。さ らに, ASIC $2 / 3$ の遺伝子ノックアウトでは，前 述した培養 DRG ニューロンの機械活性化電流 に対する明らかな効果は認められなかった9)。

\section{TRP channels}

TRPP, TRPV, TRPM, TRPA, TRPC, TRPML の 6 種類のサブファミリーから成り, 遺伝子は 29 種類にも及ぶ。内耳有毛細胞や肺 静脈心筋細胞のメカノセンサー候補になるな ど，機械刺激応答の分子機構として最も注目さ れている5)。中でも，TRPV4 と $\mathrm{N}$ 末端に多く のアンキリンリピート構造を持つ TRPA1 は, チャネルの特性から触覚応答への関与が示唆さ れてきた（Fig.2）。しかしながら，それらの遺 伝子ノックアウトでは, 侵害刺激強度の機械刺 


\begin{tabular}{|c|c|c|}
\hline Superfamily & Family & Member \\
\hline $\mathrm{DEG} / \mathrm{ENaC}$ & $\begin{array}{c}\text { ENaC } \\
\text { ASIC } \\
\text { Stomatin/MEC-2 }\end{array}$ & $\begin{array}{l}\alpha-E N a C \\
\beta \text {-ENaC } \\
\text { Y-ENaC } \\
\text { ASIC1 } \\
\text { ASIC2 } \\
\text { ASIC3 } \\
\text { SLP3 }\end{array}$ \\
\hline TRP & $\begin{array}{l}\text { TRPV } \\
\text { TRPA } \\
\text { TRPC } \\
\text { TRPN } \\
\end{array}$ & $\begin{array}{l}\text { TRPV4 } \\
\text { TRPA1 } \\
\text { TRPC3 } \\
\text { TRPC6 } \\
\text { NOMPC }\end{array}$ \\
\hline PIEZO & PIEZO & $\begin{array}{l}\text { PIEZO1 } \\
\text { PIEZO2 }\end{array}$ \\
\hline
\end{tabular}

Fig.2 Putative mechanically activated channels. Top, DEG/EnaC family. Middle, TRP channel family. Bottom, Piezo channel family.

激や痛覚過敏でのみ効果が得られたと報告され ている 1,17)。行動穾験で触刺激応答の低下が確 認された TRPC3/6 ノックアウトマウスにおい ても，DRGニューロンで記録された機械活性 化電流への影響は認めなかった 28)。

現時点においては，哺乳類に発現する ASIC や TRP が機械刺激によって直接開口するとい う明確な証明はそしいが，Stomatin-like protein 3 (C. elegance の MEC2 相同体) のような修飾 蛋白と連合して機能している可能性は否定で きない34)。こうしたなか，これまでの候補 チャネルと異なる蛋白が 2010 年に Coste らに よって報告された。その蛋白が, ギリシャ語で 圧力を意味するPiezo である 6)。

\section{Piezo}

Piezo1 と Piezo2 の 2 種類のメンバーが同定 されている (Fig.2)。いずれも30４0 回に及ぶ 膜貫通部位を持ち，4量体になってチャネル孔 を構成すると考えられている7)。HEK293 細胞 に発現させたPiezoが，機械刺激に対して確か
に応答電流を発生することや，マウス培養 DRG ニューロンから得られた機械活性化電流 が，Piezo2のノックダウンによって減弱する ことが明らかになった。哺乳類において同定さ れ，その機能が証明された数少ない機械活性化 チャネルの1つとして注目度が高まり，触覚だ けでなく赤血球のボリュームコントロールなど 機械刺激応答を必要とする生理現象への関与も 示されている2)。また，DRGニューロン内の cAMP 感知蛋白である EPAC1 が，Piezo2 を活 性化し触覚性疼痛を成立することや，Piezo1 と Piezo2 が連携して関節軟骨障害を助長する といった病態生理の新たな知見も報告され始め ている 10,15)。

\section{Piezo2 は Merkel 触盤の触覚検出を担う}

Merkel 細胞で記録した電流特性が，Piezo 電流に類似していたことから，RT-PCR でそ の遺伝子発現量を確認したところ，メンバーの 1つであるPiezo2 が特異的に発現しているこ とがわかった。レンチウイルスを用いた遺伝子 ノックダウンによって，発現量だけでなく機能 的にも機械活性化電流抒よび求心性神経に生じ る SA I 応答が減弱することから, Merkel 細胞 のメカノトランスダクションは Piezo2によっ て担われていることが明らかになった ${ }^{13)}$ 。 Merkel 細胞に特異的に発現する転写因子 Atoh1 にGFP を導入して作製したトランス ジェニックマウスに扗いても，培養表皮 Merkel 細胞が Piezo2 を介して機械刺激に応答 することが示された ${ }^{23)}$ 。さらに, Merkel 細胞 に発現するPiezo2 のみをノックアウトした条 件付遺伝子破壊では，SA I の初期動的応答が 


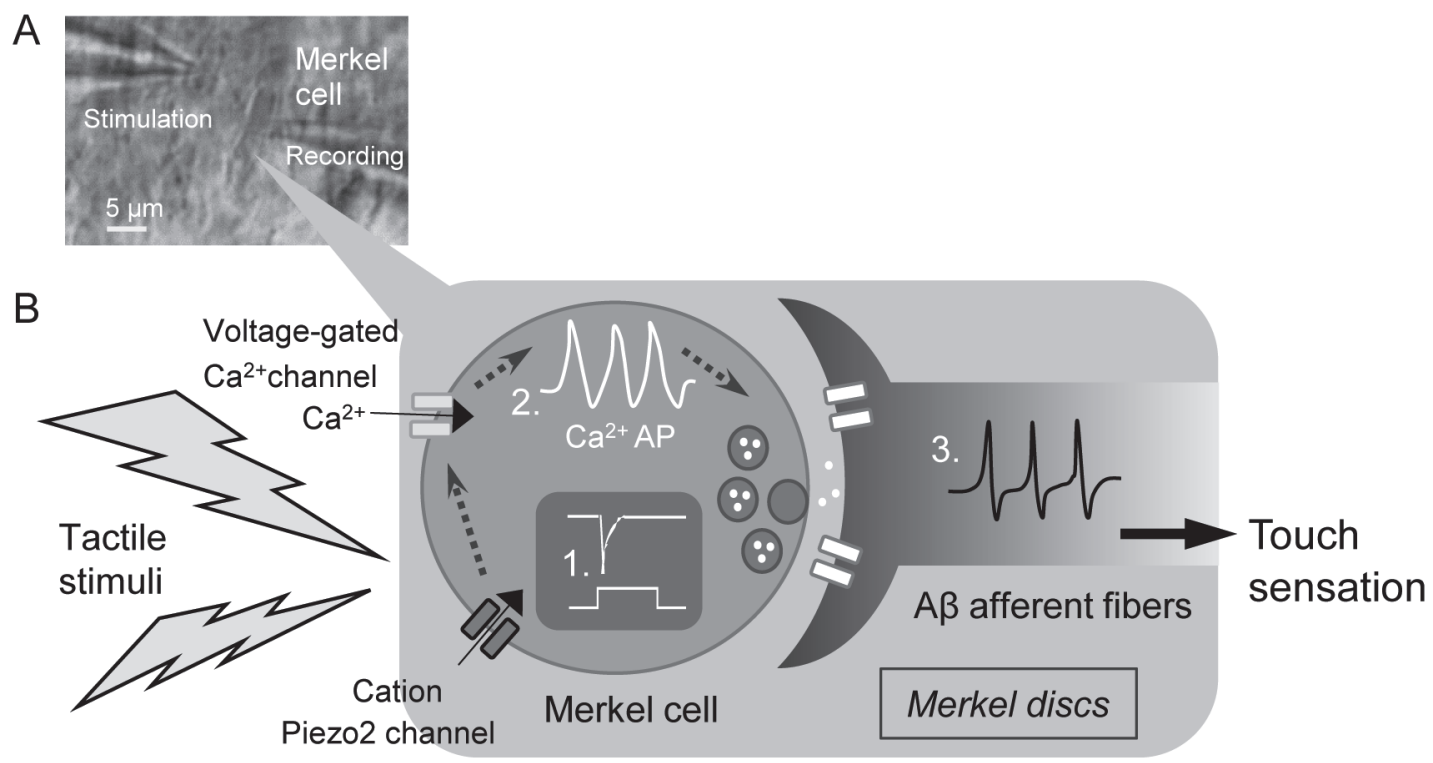

Fig.3 Tactile transdcution in Merkel discs.

A) The image of mechanical stimulation during patch-clamp recordings from Merkel cells in situ.

B ) 1: Merkel cells transduce tactile stimuli to mechanically activated currents. 2: Merkel cell's action potentials (AP) are mediated by voltage-gated $\mathrm{Ca}^{2+}$ channel. 3: Mechanotransduction of Merkel cells drive SA impulses in $\mathrm{A} \beta$ afferent fibers.

変わらず残存したため，接続する $\mathrm{A} \beta$ 求心性神 経終末に発現する Piezo2 も協同的に機能して, 求心性線維にインパルスを惹起することが示唆 された ${ }^{35)}$ 。行動学的にも Piezo2 の遺伝子操作 は，個体の触覚応答を減少させることから，優 しい触刺激は Merkel 触盤の Piezo2 を介して 検出され，確かに触覚として認識される事実が 明らかになった ${ }^{13,35) 。 ~}$

\section{おわりに}

Merkel 細胞は外界からの機械刺激を形質膜 に発現するPiezo2 チャネルの開口によって電 流変換し, 細胞を興奮させて電位依存性 $\mathrm{Ca}^{2+}$ チャネルの活性化を導きシナプス電位を発生す
る。この活動電位は減衰することなくシナプス 近傍へ伝播され神経伝達物質を放出し, $\mathrm{A} \beta$ 求 心性神経に SA I を惹起する（Fig.3）。この一連 の触知覚伝達メカニズムが明らかになり，これ まで得体の知れなかった細胞は，繊細で敏感な 触刺激応答を担う感覚細胞であることが証明さ

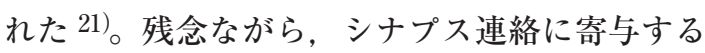
主要神経伝達物質については未解明のままであ り, 引き続きの検討課題になっている。今後, Piezo を含めた機械活性化チャネルの研究が飛 躍的に発展することで, Merkel 触盤以外の触 覚受容器だけでなく，筋肉，腱，勒帯に存在す る固有受容器においても機械刺激検出の詳細な 細胞分子機構が明らかになるものと考える ${ }^{36) 。}$ これにより, 触覚性障害や運動器疾患の病態解 明も進み，これまでにない新たな治療法の確立 や創薬の進展に繋がることが期待される。 


\section{文 献}

1) Alessandri-Haber, N., Dina, O.A., Yeh, J.J., Parada, C.A., Reichling, D.B., Levine, J.D., Transient receptor potential vanilloid 4 is essential in chemotherapy-induced neuropathic pain in the rat, J. Neurosci., 24 (2004) 4444-4452.

2) Cahalan, S.M., Lukacs, V., Ranade, S.S., Chien, S., Bandell, M., Patapoutian, A., Piezo1 links mechanical forces to red blood cell volume, eLife, 4 (2015) e07370.

3) Cha, M., Ling, J., Xu, G.Y., Gu, J.G., Shear mechanical force induces an increase of intracellular Ca2+ in cultured Merkel cells prepared from rat vibrissal hair follicles, J. Neurophysiol., 106 (2011) 460-469.

4) Chalfie, M., Neurosensory mechanotransduction, Nat. Rev. Mol. Cell Biol., 10 (2009) 4452.

5) Christensen, AP., Corey, DP., TRP channels in mechanosensation: direct or indirect activation?, Nat. Rev. Neurosci., 8 (2007) 510-521.

6) Coste, B., Mathur, J., Schmidt, M., Earley, T.J., Ranade, S., Petrus, M.J., Dubin, A.E., Patapoutian, A., Piezol and Piezo2 are essential components of distinct mechanically activated cation channels, Science, 330 (2010) 55-60.

7) Coste, B., Xiao, B., Santos, J.S., Syeda, R., Grandl, J., Spencer, K.S., Kim, S.E., Schmidt, M., Mathur, J., Dubin, A.E., Montal, M., Patapoutian, A., Piezo proteins are poreforming subunits of mechanically activated channels, Nature, 483 (2012) 176-181.

8) Delmas, P., Hao, J., Rodat-Despoix, L., Molecular mechanisms of mechanotransduction in mammalian sensory neurons, Nat. Rev. Neurosci., 12 (2011) 139-153.

9) Drew, L.J., Rohrer, D.K., Price, M.P., Blaver, K.E., Cockayne, D.A., Cesare, P., Wood, J.N., Acid-sensing ion channels ASIC2 and ASIC3 do not contribute to mechanically activated currents in mammalian sensory neurones, J. Physiol., 556 (2004) 691-710.

10) Eijkelkamp, N., Linley, J.E., Torres, J.M., Bee, L., Dickenson, A.H., Gringhuis, M., Minett, M.S., Hong, G.S., Lee, E., Oh, U., Ishikawa, Y., Zwartkuis, F.J., Cox, J.J., Wood, J.N., A role for Piezo2 in EPAC1-dependent mechanical allodynia, Nat. Commun., 4 (2013) 1682.

11) Gottschaldt, K.M., Vahle-Hinz, C., Merkel cell receptors: structure and transducer function, Science, 214 (1981) 183-186.
12) Halata, Z., Grim, M., Bauman, K.I., Friedrich Sigmund Merkel and his "Merkel cell", morphology, development, and physiology: review and new results, Anat. Rec. A Discov. Mol. Cell. Evol. Biol., 271 (2003) 225-239.

13) Ikeda, R., Cha, M., Ling, J., Jia, Z., Coyle, D., $\mathrm{Gu}$ J.G., Merkel cells transduce and encode tactile stimuli to drive $\mathrm{A} \beta$-afferent impulses, Cell, 157 (2014) 664-675.

14) Ikeda, R., Ling, J., Cha, M., Gu, J.G., In situ patch-clamp recordings from Merkel cells in rat whisker hair follicles, an experimental protocol for studying tactile transduction in tactile-end organs, Mol. Pain, 11 (2015) 23.

15) Johnson, K.O., The roles and functions of cutaneous mechanoreceptors, Curr. Opin. Neurobiol., 11 (2001) 455-461.

16) Jurmain, J.C., Blancero, A.J., Geiling, J.A., Bennett, A., Jones, C., Berkley, J., Vollenweider, M., Minsky, M., Bowersox, J.C., Rosen J.M., HazBot: Development of a telemanipulator robot with haptics for emergency response, Am. J. Disaster Med., 3 (2008) 87-97.

17) Kwan, K.Y., Allchorne, A.J., Vollrath, M.A., Christensen, A.P., Zhang, D.S., Woolf, C.J., Corey, D.P., TRPA1 contributes to cold, mechanical, and chemical nociception but is not essential for hair-cell transduction, Neuron, 50 (2006) 277-289.

18) Lee, W., Leddy, H.A., Chen, Y., Lee, S.H., Zelenski, N.A., McNulty, A.L., Wu, J., Beicker, K.N., Coles, J., Zauscher, S., Grandl, J., Sachs, F., Guilak, F., Liedtke, W.B., Synergy between Piezo1 and Piezo2 channels confers highstrain mechanosensitivity to articular cartilage, Proc. Natl. Acad. Sci. USA, 11 (2014) E511422.

19) Lou, S., Duan, B., Vong, L., Lowell, B.B., Ma, Q., Runx1 controls terminal morphology and mechanosensitivity of VGLUT3-expressing C-mechanoreceptors, J. Neurosci., 33 (2013) 870-882.

20) Lumpkin, E.A., Marshall, K.L., Nelson, A.M., The cell biology of touch, J. Cell Biol., 191 (2010) 237-248.

21) Ma, Q., Merkel cells are a touchy subject, Cell, 157 (2014) 531-533.

22) Maksimovic, S., Baba, Y., Lumpkin, E.A., Neurotransmitters and synaptic components in the Merkel cell-neurite complex, a gentletouch receptor, Ann. NY Acad. Sci., 1279 (2013) 13-21.

23) Maksimovic, S., Nakatani, M., Baba, Y., 
Molecular and cellular mechanisms underlying the tactile sensation

Nelson, A.M., Marshall, K.L., Wellnitz, S.A., Firozi, P., Woo, S.H., Ranade, S., Patapoutian, A., Lumpkin, E.A., Epidermal Merkel cells are mechanosensory cells that tune mammalian touch receptors, Nature, 509 (2014) 617-621.

24) Maricich, S.M., Wellnitz, S.A., Nelson, A.M., Lesniak, D.R., Gerling, G.J., Lumpkin, E.A., Zoghbi, H.Y., Merkel cells are essential for light-touch responses, Science, 324 (2009) 1580-1582.

25) McCarter, G.C., Reichling, D.B., Levine, J.D., Mechanical transduction by rat dorsal root ganglion neurons in vitro, Neurosci. Lett., 273 (1999) 179-182.

26) O'Hagan, R., Chalfie, M., Goodman, M.B., The MEC-4 DEG/ENaC channel of Caenorhabditis elegans touch receptor neurons transduces mechanical signals, Nat. Neurosci., 8 (2005) 43-50.

27) Page, A.J., Brierley, S.M., Martin, C.M., Martinez-Salgado, C., Wemmie, J.A., Brennan, T.J., Symonds, E., Omari, T., Lewin, G.R., Welsh, M.J., Blackshaw, LA., The ion channel ASIC1 contributes to visceral but not cutaneous mechanoreceptor function, Gastroenterology, 127 (2004) 1739-1747.

28) Quick, K., Zhao, J., Eijkelkamp, N., Linley, J.E., Rugiero, F., Cox, J.J., Raouf, R., Gringhuis, M., Sexton, J.E., Abramowitz, J., Taylor, R., Forge, A., Ashmore, J., Kirkwood, N., Kros, C.J., Richardson, G.P., Freichel, M., Flockerzi, V., Birnbaumer, L., Wood, J.N., TRPC3 and TRPC6 are essential for normal mechanotransduction in subsets of sensory neurons and cochlear hair cells, Open Biol., 2 (2012) 120068.

29) Raspopovic, S., Capogrosso, M., Petrini, F.M., Bonizzato, M., Rigosa, J., Di Pino, G., Carpaneto, J., Controzzi, M., Boretius, T., Fernandez, E., Granata, G., Oddo, C.M., Citi, L., Ciancio, A.L., Cipriani, C., Carrozza, M.C., Jensen, W., Guglielmelli, E., Stieglitz, T., Rossini, PM., Micera, S., Restoring natural sensory feedback in real-time bidirectional hand prostheses, Sci. Transl. Med., 6 (2014) 222.

30) Reinisch, C.M., Tschachler, E., The touch dome in human skin is supplied by different types of nerve fibers, Ann. Neurol., 58 (2005) 88-95.
31) Roza, C., Puel, J.L., Kress, M., Baron, A., Diochot, S., Lazdunski, M., Waldmann, R., Knockout of the ASIC2 channel in mice does not impair cutaneous mechanosensation, visceral mechanonociception and hearing, J. Physiol., 5588 (2004) 659-669.

32) Tazaki, Y., Tazaki, M., Inoue, T., Shimono, M., Scanning and transmission electron microscopic observation of changes in cylindrical cytoplasmic processes of isolated single Merkel cell, Bull. Tokyo Dent. Coll., 52 (2011) 69-76.

33) von Hehn, C.A., Baron, R., Woolf, C.J., Deconstructing the neuropathic pain phenotype to reveal neural mechanisms, Neuron, 73 (2012) 638-652.

34) Wetzel, C., Hu, J., Riethmacher, D., Benckendorff, A., Harder, L., Eilers, A., Moshourab, R., Kozlenkov, A., Labuz, D., Caspani, O., Erdmann, B., Machelska, H., Heppenstall, P.A., Lewin, G.R., A stomatindomain protein essential for touch sensation in the mouse, Nature, 445 (2007) 206-209.

35) Woo, S.H., Ranade, S., Weyer, A.D., Dubin, A.E., Baba, Y., Qiu, Z., Petrus, M., Miyamoto, T., Reddy, K., Lumpkin, E.A., Stucky, C.L., Patapoutian, A., Piezo2 is required for Merkelcell mechanotransduction, Nature, 509 (2014) 622-626.

36) Woo, S.H., Lukacs, V., de Nooij, J.C., Zaytseva, D., Criddle, C.R., Francisco, A., Jessell, T.M., Wilkinson, K.A., Patapoutian, A., Piezo2 is the principal mechanotransduction channel for proprioception, Nat. Neurosci., 18 (2015) 1756-1762.

37) Yamashita, Y., Akaike, N., Wakamori, M., Ikeda, I., Ogawa, H., Voltage-dependent currents in isolated single Merkel cells of rats, J. Physiol., 450 (1992) 143-162.

38) Yan, Z., Zhang, W., He, Y., Gorczyca, D., Xiang, Y., Cheng, L.E., Meltzer, S., Jan, L.Y., Jan, Y.N., Drosophila NOMPC is a mechanotransduction channel subunit for gentle-touch sensation, Nature, 493 (2013) 221-225.

Address for correspondence: Ryo Ikeda

Department of Orthopaedic Surgery,

Jikei University School of Medicine

3-25-8 Nishi-Shimbashi, Minato-ku,Tokyo, 105-8461, Japan 